\title{
Effect of straw particle size on the behavior, health, and production of early-lactation dairy cows
}

\author{
R. E. Coon, ${ }^{*}$ T. F. Duffield, † and T. J. DeVries*1 \\ *Department of Animal Biosciences, and \\ †Department of Population Medicine, University of Guelph, Guelph, Ontario, N1G 2W1, Canada
}

\begin{abstract}
The objective of this study was to determine the effect of reducing the particle size of wheat straw in a total mixed ration (TMR) on cow behavior, health, and production in early lactation. For $28 \mathrm{~d}$ after calving, 41 multiparous Holstein cows were individually provided either 1 of 2 TMR with $9 \%$ wheat straw (dry matter basis) chopped (1) using a 2.54-cm screen (short; $\mathrm{n}=21$ ) or (2) using a 5.08 -cm screen (long; $\mathrm{n}=20$ ). Cows were housed in freestall pens during both the dry and lactating period. Enrollment in the trial was on a rolling basis and cows were evenly distributed by parity and milk production between treatments. Wireless telemetry boluses were used to measure reticulorumen $\mathrm{pH}$. Automated systems recorded TMR dry matter intake, milk yield, and rumination activity. The TMR and orts samples were collected every $3 \mathrm{~d}$ to determine feed sorting. A particle separator was used to separate feed samples into 4 fractions: long $(>19 \mathrm{~mm})$, medium $(<19 \mathrm{~mm},>8 \mathrm{~mm})$, short $(<8 \mathrm{~mm},>4 \mathrm{~mm})$, and fine $(<4 \mathrm{~mm})$ particles. Feed sorting was calculated as actual intake of each particle fraction expressed as a percentage of its predicted intake. Cows sorted the longest TMR particles differently by treatment; on the long treatment cows sorted against long particles (94.2 $\pm 1.9 \%$ ), whereas on the short treatment cows did not sort for or against these particles $(99.7 \pm 1.9 \%)$. Data were analyzed in mixed-effect linear regression models and fitted with polynomial functions over the $28 \mathrm{~d}$ of observations. The fitted data indicated treatment differences in linear coefficients, quadratic coefficients, and cubic coefficients for mean time (min/d) below a reticulorumen $\mathrm{pH}$ of 5.8 and milk yield. Rumination time $(\mathrm{min} / \mathrm{d})$ differed between treatments for quadratic and cubic coefficients. Cows on the short treatment linearly increased in dry matter intake at a greater rate than cows on the long treatment. Mean reticulorumen
\end{abstract}

Received September 30, 2017.

Accepted March 5, 2018.

${ }^{1}$ Corresponding author: tdevries@uoguelph.ca
$\mathrm{pH}$ decreased at a greater rate for cows on the long treatment than for cows on the short, as indicated by differences between linear coefficients. Cows on the short treatment tended to produce $75 \mathrm{~kg}$ more milk cumulatively during the first $28 \mathrm{~d}$ in milk than cows on long treatment. These results suggest that cows fed a diet with longer straw particles selected against physically effective fiber, which may have contributed to greater fluctuations in rumination time, reticulorumen $\mathrm{pH}$, dry matter intake, and milk production in early lactation.

Key words: dairy cow, sorting, $\mathrm{pH}$, rumination, straw

\section{INTRODUCTION}

When provided a TMR, dairy cows often sort their feed, typically favoring small grain components and avoiding longer forage particles (Leonardi and Armentano, 2003; Leonardi et al., 2005a; DeVries et al., 2007). Particle size of forages is one of the primary factors influencing feed sorting, with smaller particles being less easily sorted than longer particles (Miller-Cushon and DeVries, 2017). Additionally, high palatability of the concentrate components of the TMR motivates cows to sort in favor of these smaller components and against the longer forage ingredients (Nombekela et al., 1994; Miller-Cushon and DeVries, 2017).

Intake of dietary forage is important, as it primarily contributes the physically effective NDF (peNDF) portion of the diet, which is responsible for stimulating rumination and improving fiber digestibility (Yang and Beauchemin, 2006a,b; Zebeli et al., 2012). Sorting behavior can result in an over-consumption of easily fermented carbohydrates and an under-consumption of peNDF (Miller-Cushon and DeVries, 2017). This unbalanced diet, as a result of sorting, may lead to an increased risk of SARA (DeVries et al., 2008); an overconsumption of grains relative to peNDF can cause a buildup of VFA and a resultant prolonged depression of the rumen $\mathrm{pH}(<5.6-5.8$ for multiple hours per day) characteristic of SARA (Steele et al., 2016). Subacute ruminal acidosis can lead to decreased DMI, 
milk production, and fiber digestibility (Plaizier et al., 2008). Fresh cows are especially vulnerable to SARA because of the abrupt transition from a low-energy diet to a more highly fermentable diet at calving (Steele et al., 2016). It is important that transition cows are not able to easily sort their feed during this time, as this behavior likely exacerbates the condition through over consumption of easily fermented carbohydrates and under consumption of effective fiber.

Nutritional management of fresh cows can be difficult because there are competing demands for nutrientdense concentrate components to sustain lactation and for sufficient forage to maintain good rumen function. It is important that the dietary fiber in the diet be presented in a manner that discourages sorting to ensure a balanced diet that stimulates rumination. Reducing the particle size of the forage sources increases NDF intake and decreases sorting against the long particles and for fine particles (Miller-Cushon and DeVries, 2017). A forage particle size that is large enough to stimulate rumination, yet small enough to prevent sorting against the forage component may, thus, reduce the risk of SARA in early-lactation dairy cows.

The objective of our research was to determine if reducing the particle size of wheat straw in a diet for early-lactation cows would have positive effects on cow behavior, health, and production. We hypothesized that a diet with a smaller particle size wheat straw would minimize sorting behavior while maintaining DMI levels and rumination, resulting in a stabilization of reticulorumen $\mathrm{pH}$.

\section{MATERIALS AND METHODS}

\section{Animals and Housing}

Forty-one multiparous Holstein cows (parity $=2.8 \pm$ 1.1 postcalving; mean $\pm \mathrm{SD}$ ) were used in this study, which took place at the University of Guelph Livestock Research and Innovation Centre Dairy Facility (Elora, Ontario, Canada). At approximately $17 \mathrm{~d}$ before calving, cows were enrolled in the study; this time frame allowed for a minimum 3-d training period in addition to 2 wk of baseline data collection before calving. During this time, cows were housed in a close-up pen and trained to eat out of individual automated feed bins (Insentec B.V., Marknesse, the Netherlands). Each cow was assigned her own bin, and trained to eat only out of that bin during the 3 - $\mathrm{d}$ period. At approximately 2 wk before calving $(\mathrm{d}-13.4 \pm 4.9)$, cows had an average BW of $847.7 \pm 77.6 \mathrm{~kg}$ and an average BCS of $3.7 \pm$ 0.34. The close-up pen had 12 automated feed bins, 24 freestalls, and 2 water troughs. There were never more than 12 cows in the close-up pen at one time, ensuring that each cow had access to her own individual feed bin. Cows spent $3.1 \pm 3.2 \mathrm{~d}$ in the maternity pen before calving and $5.2 \pm 3.3 \mathrm{~d}$ in the maternity pen after calving. The maternity pens were individual boxstalls $(3.5 \times 4.9 \mathrm{~m})$ with individual access to feed and water. After calving, cows were milked in their maternity pens using a portable milking system.

Dry cows were fed a dry cow TMR (Tables 1 and 2) $1 \times / \mathrm{d}$ between 1000 and $1100 \mathrm{~h}$. The total amount of feed offered was adjusted daily to target approximately $10 \%$ refusals per bin (actual $=14.7 \pm 12.3 \%$ ). The dry cow feed bins were cleaned out each day at approximately $0930 \mathrm{~h}$ every morning. After calving and following exit from the maternity pens, cows were moved to a lactating pen and again assigned to an individual feed bin. The lactating cow pen had 15 automated feed bins, 30 freestalls, and 2 water troughs. There were never more than 15 cows in the lactating pen at one time, ensuring that each cow had access to her own individual feed bin. Lactating cows were fed $1 \times / d$ between 1300 and $1400 \mathrm{~h}$. The total amount of feed offered was adjusted daily to target approximately $10 \%$ refusals per bin (actual $=13.0 \pm 15.6 \%$ ). Lactating cows were milked $2 \times / \mathrm{d}$ at 0500 and $1700 \mathrm{~h}$ in a milking parlor.

The use of cows and experimental procedures complied with the guidelines of the Canadian Council on Animal Care (2009) and were approved by the University of Guelph Animal Care Committee (Animal Use Protocol \#2518).

\section{Experimental Design}

Sample size and power analyses were used to calculate (as per Morris, 1999) the minimum number of replicates needed per treatment $(\mathrm{n}=20)$ to detect a $10 \%$ level of observed mean difference for the primary outcome variables, including DMI, rumination, sorting, and milk production. Estimates of variation for these variables were based on previously reported values (DeVries et al., 2007; DeVries and Gill, 2012). Due to the likelihood of technical complications associated with the monitoring equipment used in our study, more than 20 cows per treatment were initially enrolled in the study to ensure the target sample size was achieved.

Upon calving, cows were randomly assigned to 1 of 2 dietary treatments (Table 1, 2), a TMR that differed in the length of the wheat straw component in that diet (Table 2), specifically (1) straw chopped with a $2.54-\mathrm{cm}$ screen (short; $\mathrm{n}=21$ ) or $(2)$ straw chopped with a 5.08$\mathrm{cm}$ screen (long; $\mathrm{n}=20$ ) For both treatments, straw was chopped using a bale processor (Haybuster Model H-1150, Jamestown, ND). Cows were fed these treatment diets from 1 to 28 DIM. Treatment allocation was reviewed throughout the study to ensure it was 
Table 1. Ingredient and chemical composition (mean $\pm \mathrm{SD}$ ) of the dry cow and experimental TMR

\begin{tabular}{|c|c|c|c|}
\hline \multirow[b]{2}{*}{ Composition } & \multirow[b]{2}{*}{ Dry diet } & \multicolumn{2}{|c|}{ Lactation diet } \\
\hline & & Long straw ${ }^{1}$ & Short straw ${ }^{2}$ \\
\hline \multicolumn{4}{|l|}{ Ingredient (\% DM) } \\
\hline Corn silage $^{3}$ & 42 & 34 & 34 \\
\hline Wheat straw ${ }^{4}$ & 21 & $9^{5}$ & $9^{6}$ \\
\hline Alfalfa haylage $^{5}$ & 16 & 26 & 26 \\
\hline High-moisture corn & - & 19 & 19 \\
\hline Dry cow supplement ${ }^{6}$ & 21 & - & - \\
\hline Lactating cow supplement $^{7}$ & - & 12 & 12 \\
\hline \multicolumn{4}{|l|}{ Chemical composition $^{8}$} \\
\hline DM (\% & $48.3 \pm 2.9$ & $49.0 \pm 3.9$ & $49.0 \pm 4.8$ \\
\hline $\mathrm{OM}(\%$ of $\mathrm{DM})$ & $92.2 \pm 0.5$ & $91.8 \pm 0.8$ & $92.1 \pm 0.8$ \\
\hline $\mathrm{CP}(\%$ of $\mathrm{DM})$ & $13.6 \pm 1.0$ & $15.9 \pm 2.0$ & $15.5 \pm 1.8$ \\
\hline $\mathrm{ADF}(\%$ of $\mathrm{DM})$ & $30.5 \pm 1.3$ & $22.4 \pm 1.9$ & $22.7 \pm 1.7$ \\
\hline $\mathrm{NDF}(\%$ of $\mathrm{DM})$ & $44.1 \pm 1.8$ & $32.6 \pm 2.7$ & $33.0 \pm 2.5$ \\
\hline Starch (\% of DM) & $17.0 \pm 1.2$ & $26.1 \pm 2.0$ & $26.4 \pm 2.4$ \\
\hline $\mathrm{NFC}(\%$ of $\mathrm{DM})$ & $34.6 \pm 1.8$ & $43.3 \pm 2.3$ & $43.5 \pm 3.0$ \\
\hline $\mathrm{Ca}(\%$ of DM) & $1.0 \pm 0.1$ & $1.1 \pm 0.2$ & $1.1 \pm 0.1$ \\
\hline $\mathrm{P}(\%$ of $\mathrm{DM})$ & $0.4 \pm 0.0$ & $0.5 \pm 0.1$ & $0.5 \pm 0.1$ \\
\hline $\mathrm{NE}_{\mathrm{L}}(\mathrm{Mcal} / \mathrm{kg}$ of $\mathrm{DM})$ & $1.52 \pm 0.02$ & $1.63 \pm 0.03$ & $1.63 \pm 0.03$ \\
\hline
\end{tabular}

${ }^{1}$ Straw in long lactating diet was chopped using a 5.08-cm screen.

${ }^{2}$ Straw in short lactating diet was chopped using a $2.54-\mathrm{cm}$ screen.

${ }^{3}$ Corn silage had a DM of $41.1 \pm 8.0 \%$ and chemical composition (DM basis) of $7.3 \pm 0.6 \% \mathrm{CP}, 18.6 \pm 1.5 \%$ $\mathrm{ADF}, 30.6 \pm 1.8 \% \mathrm{NDF}$, and $40.8 \pm 0.7 \%$ starch.

${ }^{4}$ Straw had a DM of $90.0 \pm 2.9 \%$ and chemical composition (DM basis) of $4.8 \pm 0.7 \% \mathrm{CP}, 55.6 \pm 1.1 \%$ ADF, and $77.4 \pm 1.1 \%$ NDF.

${ }^{5}$ Alfalfa $(80 \%)$ and timothy grass $(20 \%)$ haylage had a DM of $39.7 \pm 6.3 \%$ and chemical composition (DM basis) of $17.6 \pm 1.5 \% \mathrm{CP}, 35.3 \pm 0.5 \% \mathrm{ADF}$, and $41.4 \pm 2.3 \% \mathrm{NDF}$.

${ }^{6}$ Manufactured and supplied by Floradale Feed Mill Ltd. (Floradale, Ontario, Canada) including ingredients (\% of DM) $38.2 \%$ Soy Plus, $20.2 \%$ soy hulls (ground), $19.1 \%$ canola, $15.3 \%$ wheat shorts, $9.6 \%$ soybean meal, $2.2 \%$ Diamond V Yeast XP, $2.1 \%$ limestone calcium carbonate, $1.5 \%$ magnesium oxide, $1.1 \%$ vitamin E, $1.1 \%$ fine salt, 1.1\% tallow, 0.6\% FFM Org Ruminant Micro PRX, 0.08\% Alkosel 2000, 0.06\% Rumensin, and 0.01\% Rovimix Biotin 20,000.

${ }^{7}$ Manufactured and supplied by Floradale Feed Mill Ltd. including ingredients (\% of DM) 49.1\% Soy Plus, $35.9 \%$ soybean meal, $4.6 \%$ limestone calcium carbonate, $4.3 \%$ sodium sesquicarbonate, $4.0 \%$ fine salt, $3.9 \%$ fish meal (herring), 3.0\% monocalcium phosphate, $2.2 \%$ magnesium oxide, $2.0 \%$ Diamond V Yeast XP, 1.0\% FFM Org Ruminant Micro P, 0.4\% Metasmart, 0.06\% Rumensin, and 0.03\% Selplex 2000.

${ }^{8}$ Values were obtained from chemical analysis of TMR samples. OM $=100-\%$ ash. NFC $=100-(\% \mathrm{CP}+$ $\% \mathrm{NDF}+\%$ fat $+\%$ ash). $\mathrm{NE}_{\mathrm{L}}$ was calculated based on NRC (2001) equations.

balanced for parity and milk production in the previous lactation $(10,334.4 \pm 1,955.7 \mathrm{~kg})$. Each day, the basal diet, without straw, was prepared using a TMR mixer (Jaylor Model 5572, Jaylor Fabricating, Orton, ON, Canada). Feed was then transferred to a feed cart (Super Data Ranger; American Calan, Northwood, NH) and the appropriate amount of straw was added and mixed before delivery. Cows remained on their respective treatments for $4 \mathrm{wk}$ postcalving. The lactating cow TMR was formulated to attempt, at minimum, to meet the nutrient requirements of early-lactation dairy cows producing $36 \mathrm{~kg} / \mathrm{d}$ (NRC, 2001).

\section{Behavioral Data Collection}

Feeding behavior and DMI were monitored using the automated feed bins, as validated by Chapinal et al. (2007). From the recorded data, the duration of each visit to the feed bin, the amount of feed consumed (start weight - end weight) during each visit, and the rate of consumption for each visit were calculated. These data were then summarized to calculate daily DMI $(\mathrm{kg} / \mathrm{d})$, daily time spent feeding $(\mathrm{min} / \mathrm{d})$, and average feeding rate $(\mathrm{kg} / \mathrm{min})$. Individual feeding bouts were combined and separated into meals using a meal criterion (i.e., the minimum duration of time between meals) calculated for each cow. Meal criteria for both the dry period and lactating period were calculated for each cow using methods described by DeVries et al. (2003); a software package (MIX 3.1.3; MacDonald and Green, 1988) was used to fit normal distributions to the frequency of $\log _{10}$-transformed intervals of time between feeding visits. Meal frequency (no./d) was determined for each cow by summarizing the number of intervals between feeding events that exceeded their meal criterion. Meal length ( $\mathrm{min} / \mathrm{meal})$ was calculated as the time between 
the start of the first feeding visit, until the end of the last visit within the meal criterion. Meal size ( $\mathrm{kg}$ of $\mathrm{DM} /$ meal) was calculated as DMI divided by meal frequency.

An electronic monitoring system (HR-TAG-LD, SCR Engineers Ltd., Netanya, Israel) was used to monitor rumination activity, as validated by Schirmann et al. (2009). Rumination data loggers, attached to a nylon neck collar, were fitted to each cow 2 wk before their expected calving date. Until the cow gave birth, and then for the first $4 \mathrm{wk}$ of lactation, rumination activity was monitored $24 \mathrm{~h} / \mathrm{d}$. The system contained a radio frequency reader, which allowed data from the collars to be continuously uploaded to the control unit. These data, stored in 2-h intervals, were used to determine total time spent ruminating throughout each day.

\section{Health Data Collection}

At the time of enrollment, cow BW was recorded (I-20W scale, Ohaus, Dundas, ON, Canada) and BCS was recorded using a 5-point scale, as described by

Table 2. Particle size distribution ${ }^{1}(\% \mathrm{DM})$ of the straw, the experimental lactating cow diets (including straw), and the chemical composition of the particle fractions of those diets (mean $\pm \mathrm{SD}$ )

\begin{tabular}{|c|c|c|}
\hline \multirow[b]{2}{*}{ Item } & \multicolumn{2}{|c|}{ Lactation diet } \\
\hline & $\begin{array}{l}\text { Long } \\
\text { straw }^{2}\end{array}$ & $\begin{array}{l}\text { Short } \\
\text { straw }^{3}\end{array}$ \\
\hline \multicolumn{3}{|c|}{ Straw (\% of DM) } \\
\hline 19-mm sieve & $14.1 \pm 6.9$ & $1.4 \pm 0.8$ \\
\hline 8-mm sieve & $39.8 \pm 4.7$ & $25.0 \pm 4.8$ \\
\hline 4-mm sieve & $17.4 \pm 1.0$ & $24.8 \pm 1.7$ \\
\hline$<4$-mm pan & $28.6 \pm 10.5$ & $48.9 \pm 3.4$ \\
\hline \multicolumn{3}{|c|}{ TMR (\% of DM; including straw) } \\
\hline 19-mm sieve & $6.4 \pm 4.2$ & $4.2 \pm 3.6$ \\
\hline $8-\mathrm{mm}$ sieve & $38.9 \pm 5.7$ & $39.4 \pm 6.2$ \\
\hline 4-mm sieve & $19.3 \pm 2.3$ & $20.5 \pm 3.4$ \\
\hline$<4-m m$ pan & $35.4 \pm 7.0$ & $36.0 \pm 7.0$ \\
\hline \multicolumn{3}{|c|}{$\mathrm{ADF}^{4}(\%$ of screen $\mathrm{DM})$} \\
\hline 19-mm sieve & $31.5 \pm 1.0$ & $28.9 \pm 1.2$ \\
\hline 8-mm sieve & $26.6 \pm 0.9$ & $25.8 \pm 1.0$ \\
\hline 4-mm sieve & $18.6 \pm 0.5$ & $19.5 \pm 1.0$ \\
\hline$<4-\mathrm{mm}$ pan & $13.9 \pm 0.5$ & $15.2 \pm 1.2$ \\
\hline \multicolumn{3}{|c|}{$\mathrm{NDF}^{4}(\%$ of screen DM) } \\
\hline 19-mm sieve & $45.2 \pm 1.2$ & $40.7 \pm 1.9$ \\
\hline 8-mm sieve & $37.7 \pm 1.6$ & $36.6 \pm 2.0$ \\
\hline 4-mm sieve & $28.2 \pm 1.0$ & $29.4 \pm 1.8$ \\
\hline$<4-\mathrm{mm}$ pan & $21.2 \pm 1.0$ & $23.7 \pm 1.7$ \\
\hline
\end{tabular}

${ }^{1}$ Particle size determined by Penn State particle separator (Nasco, Fort Atkinson, WI), which has a 19-mm screen (long), 8-mm screen (medium), 4-mm screen (short), and a pan (fine).

${ }^{2}$ Straw in the long lactating diet was chopped using a $5.08-\mathrm{cm}$ screen. ${ }^{3}$ Straw in the short lactating diet was chopped using a $2.54-\mathrm{cm}$ screen. ${ }^{4}$ Values were obtained from chemical analysis of separated TMR samples.
Wildman et al. (1982). Assessment of BW and BCS occurred once during the dry period at enrollment and every $14 \mathrm{~d}$ starting on d 4 postcalving for a total of 3 measurements, including a final weighing on the last day of the trial period. To ensure accuracy for BCS, interobserver reliability testing was conducted between 3 individuals, with a resultant $85 \%$ accuracy rate. One of these individuals conducted the BCS for the entirety of the trial.

Wireless telemetry boluses (eBolus, eCow Ltd., Devon, UK) were used to measure reticulorumen $\mathrm{pH}$ to assess rumen health (as validated by Falk et al., 2016). At time of enrollment, the boluses were administered orally using a balling gun. Data consisted of reticulorumen $\mathrm{pH}$ data points at 15-min intervals for $24 \mathrm{~h} / \mathrm{d}$ throughout the trial period. Data were downloaded 3 $\mathrm{d} /$ wk during the dry period and every $3 \mathrm{~d}$ postcalving. Data were amalgamated into a continuous record for each individual cow. Time spent below a $\mathrm{pH}$ threshold of 5.8 was then calculated along with daily mean, minimum, and maximum $\mathrm{pH}$ values. An absolute value for area below $\mathrm{pH} 5.8$ was calculated by subtracting the $\mathrm{pH}$ value from 5.8 and multiplying it by the time spent at that $\mathrm{pH}$ value. These values were summed by day, creating a single value for area under the curve (AUC) for each day for each cow. These values were also standardized for intake by dividing by DMI for each day for each cow (Penner et al., 2009).

Blood BHB was assessed weekly before calving starting on the day of enrolment and every $4 \mathrm{~d}$ postcalving starting on d 4 after calving. For blood sampling, cows were restrained in a stall to obtain a small blood sample $(\sim 0.5 \mathrm{~mL})$ from the coccygeal vein. Blood BHB was measured using an electronic hand-held device (FreeStyle Precision Neo, Abbott Diabetes Care, Saint Laurent, QC, Canada), as validated by Kanz et al. (2015). Blood BHB concentrations $>1.2 \mathrm{mmol} / \mathrm{L}$ were deemed indicative of subclinical ketosis (SCK; Geishauser et al., 1998; McArt et al., 2012). Testing of BHB occurred just before feed delivery $(0930 \mathrm{~h}$ for dry cows and 1230 $\mathrm{h}$ for lactating cows) throughout the study.

\section{Milk Yield and Components}

Milk yield was recorded at every milking in the milking parlor (using DelPro software, DeLaval, Peterborough, ON, Canada) for the 4 wk cows were observed on treatment. Milk samples were collected from each cow, at each milking, on 2 consecutive days each week starting at $\mathrm{d} 6$. These samples were sent to a DHI testing laboratory (CanWest DHI, Guelph, ON, Canada) for component analysis (fat, CP, MUN, and SCC) using a Fourier Transform Infrared full-spectrum analyzer 
(Milkoscan FT+ and Milkoscan 6000; Foss, Hillerød, Denmark). One compositional value per cow on each sampling day was obtained by calculating the average across milkings.

Milk composition samples were used to determine the yield of $4 \% \mathrm{FCM}(\mathrm{kg} / \mathrm{d})$, calculated as $[0.4 \times$ milk yield $(\mathrm{kg} / \mathrm{d})]+[15.0 \times$ fat yield $(\mathrm{kg} / \mathrm{d})](\mathrm{NRC}, 2001)$. Energy-corrected milk was calculated as ECM $(\mathrm{kg} / \mathrm{d})$ $=(0.327 \times \mathrm{kg}$ of milk $)+(12.95 \times \mathrm{kg}$ of fat $)+(7.2 \times$ $\mathrm{kg}$ of protein) (Tyrrell and Reid, 1965). Efficiency of milk production was calculated as kilograms of milk, $4 \%$ FCM yield, and ECM yield per kilogram of DMI per cow.

\section{Feed Sampling and Analysis}

Throughout the study, 2 fresh feed samples were collected $3 \times /$ wk; 1 sample was collected to determine $\mathrm{DM}$ and chemical composition and the other sample was collected to determine particle size distribution. Samples of the TMR components were also collected once monthly to be analyzed for DM and chemical composition. During the dry period, orts samples were collected $3 \times /$ week to determine particle distribution for calculation of sorting. Orts samples were collected every $3 \mathrm{~d}$ during the lactating period starting on $\mathrm{d} 4$ for the same purpose. All samples were immediately frozen at $-20^{\circ} \mathrm{C}$ until further analysis.

After a 12-h period of thawing, fresh and orts TMR samples collected for particle size analysis were processed using a 4-screen Penn State particle separator (PSPS; Maulfair et al., 2011; Jones and Heinrichs, 2013), which separates the sample into 4 fractions based on particle size as long $(>19 \mathrm{~mm})$, medium $(<19$, $>8 \mathrm{~mm})$, short $(<8,>4 \mathrm{~mm})$, and fine $(<4 \mathrm{~mm})$. Separated samples were then oven-dried at $55^{\circ} \mathrm{C}$ for $48 \mathrm{~h}$.

The sorting of each PSPS fraction was calculated (as per Leonardi and Armentano, 2003) by dividing the actual amount of feed consumed of each fraction by the predicted amount of feed consumed of that fraction and expressing it as a percentage. For each fraction, the actual amount consumed was calculated by subtracting the DM refused from the DM offered, as determined by the PSPS analysis. The predicted amount consumed for each fraction was calculated as the product of the DMI of the total diet multiplied by the DM percentage of that fraction in the fed TMR. If the sorting value equaled $100 \%$, then no sorting of the particle fraction occurred, a value $<100 \%$ indicated sorting against that particle size fraction, whereas a value $>100 \%$ indicated sorting in favor of that particle fraction.

Feed samples collected for nutrient composition analysis included the fresh TMR samples, feed components, and fresh TMR PSPS fractions. These samples were oven-dried at $55^{\circ} \mathrm{C}$ for $48 \mathrm{~h}$ and then were ground to pass through a 1-mm screen (Model 4 Wiley Laboratory Mill, Thomas Scientific, Swedesboro, NJ). Ground samples, pooled by week, were then sent to Cumberland Valley Analytical Services Inc. (Maugansville, $\mathrm{MD})$ for analysis of $\mathrm{DM}\left(135^{\circ} \mathrm{C}\right.$; AOAC International, 2000: method 930.15), ash $\left(535^{\circ} \mathrm{C}\right.$; AOAC International, 2000: method 942.05), ADF (AOAC International, 2000: method 973.18), NDF with heat-stable $\alpha$-amylase and sodium sulfite (Van Soest et al., 1991), CP ( $\times$ 6.25; AOAC International, 2000: method 990.03; Leco FP-528 Nitrogen Analyzer, Leco, St. Joseph, MI), and starch (Hall, 2009).

\section{Statistical Analyses}

All statistical analyses were conducted using SAS 9.4 software (SAS Institute Inc., Cary, NC). The experimental design used was a completely randomized design. Due to technical failures of 3 reticulorumen $\mathrm{pH}$ boluses, all analyses involving reticulorumen $\mathrm{pH}$ were conducted using a sample size of 38 cows (long, $\mathrm{n}=$ 19 ; short, $\mathrm{n}=19$ ). Remaining analyses were conducted using a sample size of 41 cows (long, $\mathrm{n}=20$; short, $\mathrm{n}=$ 21). Significance was declared at $P \leq 0.05$ and tendencies were reported if $0.05<P \leq 0.10$. If the $P$-value of an interaction term was $\leq 0.05$ it was considered, otherwise interaction terms were disregarded. Prior to analyses, data were assessed for normality using the UNIVARIATE procedure of SAS; all assumptions of normality were met for all data. Residuals were compared with determine homogeneity of variance.

To investigate the effect of dietary treatment on feed sorting, feeding behavior, DMI, rumination behavior, reticulorumen $\mathrm{pH}$, and milk production and composition, data were summarized by week of lactation ( 1 to 4) and analyzed using the MIXED procedure of SAS, treating week as a repeated measure. The model included the fixed effects of week, treatment, and the week $\times$ treatment interaction. The subject of the repeated statement was cow. Compound symmetry was selected as the covariance structure on the basis of best fit according to Schwarz's Bayesian information criterion. The PDIFF procedure was used in the LS MEANS statement for analyzing differences between the week $x$ treatment interactions when differences were detected. Covariate measures from the dry period were used for detecting differences between treatments for DMI and feeding behavior. To determine the occurrence of sorting within treatments, the summarized data for each particle size were tested for a difference from 100 using $t$-tests (Leonardi and Armentano, 2003; DeVries et al., 2007). Differences in sorting were analyzed using the previously described MIXED procedure model. 
Given the known effect of precalving BCS on risk of elevated BHB postcalving (Gillund et al., 2001), cows were categorized as having a normal dry period BCS if their dry period BCS (collected at enrolment) was $\leq 3.5$ (long: $\mathrm{n}=8$, short: $\mathrm{n}=6$ ) or as having a high dry period BCS if their dry period BCS was $>3.5$ (long: $n$ $=12$, short: $\mathrm{n}=15)$. To test the effect of treatment on blood BHB concentration, data were analyzed using the MIXED procedure of SAS, treating day of blood sampling as a repeated measure. The model included the fixed effects of day of blood sampling, treatment, dry period BCS category, and the dry period BCS category $\times$ treatment interaction. The subject of the repeated statement was cow. Compound symmetry was selected as the covariance structure based on best fit according to Schwarz's Bayesian information criterion.

In addition to determining the mean response to treatment, we also sought to understand how the response variables evolved, within treatment, over the course of the trial period. Thus, to model the changes over the 28-d postcalving period in DMI, rumination time, milk yield, mean reticulorumen $\mathrm{pH}$, and time spent below a reticulorumen $\mathrm{pH}$, an analysis of covariance was conducted to determine any significant linear, quadratic, or cubic effects of day (as per Schwaiger et al., 2013; DeVries et al., 2014). To accomplish this, data were analyzed using the MIXED procedure of SAS. The fixed effects of treatment, day, treatment $x$ day, day $^{2}$, treatment $\times \mathrm{day}^{2}$, day $^{3}$, and treatment $\times$ day $^{3}$ were tested with the random effect of cow. Starting with the highest order term, those terms that were nonsignificant $(P>0.05)$ were removed from the model in a stepwise manner until only significant $(P \leq 0.05)$ terms remained in the model. When an interaction was significant, the lower order term was removed.

\section{RESULTS}

Cows sorted the longest ration particles $(>19 \mathrm{~mm})$ differently by treatment (Table 3); cows on the long treatment sorted against the longest particles $(P<$ 0.001 ), whereas cows on the short treatment did not sort for or against those particles $(P=0.88)$. Cows on the long treatment did not sort for or against the medium particles $(<19,>8 \mathrm{~mm} ; P=0.97)$, whereas cows on the short treatment sorted in favor of those particles $(P=$ 0.03); however, a difference between treatments in sorting of the medium fraction was not detected (Table 3). Cows on the long treatment did not sort for or against the short particles $(<8,>4 \mathrm{~mm} ; P=0.19)$, whereas cows on the short treatment selected in favor of those particles $(P=0.02)$; however, we detected no difference in sorting for the short particles between treatments (Table 3$)$. Cows tended to sort the fine fraction $(<4$ $\mathrm{mm}$ ) differently by treatment (Table 3); cows on the long treatment did not sort for or against the fine fraction $(P=0.86)$, whereas cows on the short treatment sorted against this fraction $(P=0.009)$.

We found no differences between treatments detected in DMI or feeding behavior during the 4-wk study period (Table 4). The only exception was a treatment $\times$ week interaction $(P=0.02)$ for within-meal interval length (min). In the first week postcalving, cows on the long treatment tended to spend more time not eating within a meal than cows on the short treatment $(5.7 \pm 0.8$ vs. $3.6 \pm 0.8 \mathrm{~min} ; P=0.06$ ); we observed no differences in within-meal interval length between treatments for wk 2 to 4 postcalving $(P=1.0)$. Cumulative DMI over the first 28 DIM was similar between treatments (long: $494.3 \pm 16.6 \mathrm{~kg}$; short: $499.6 \pm 16.2 \mathrm{~kg} ; P=0.82$ ). No effect of treatment was detected on time spent ruminating per day during the study period (Table 4).

We noted no differences detected between treatments for mean, minimum, or maximum daily reticulorumen $\mathrm{pH}$ during the 4-wk study period (Table 5). We also found no difference between treatments in daily time spent below a reticulorumen $\mathrm{pH}$ of 5.8 or AUC for a reticulorumen $\mathrm{pH}$ of 5.8 (Table 5 ). Daily milk production, composition, component yield, and milk efficiency were not affected by treatment (Table 6 ). However, the cumulative milk yield for the 4 -wk study period tended to be different between treatments $(P=0.07)$; cows on the short treatment tended to produce more milk $(1,013.0 \pm 28.1 \mathrm{~kg})$ than cows on the long treatment $(937.8 \pm 28.8 \mathrm{~kg})$.

Eighteen cows on the long treatment $(\mathrm{n}=20)$ and 20 cows on the short treatment $(\mathrm{n}=21)$ had at least 1 blood BHB concentration reading of $\geq 1.2 \mathrm{mmol} / \mathrm{L}$

Table 3. Effect of straw particle size on the sorting $(\%)^{1}$ of lactating dairy cows in the first $28 \mathrm{~d}$ of lactation $(\text { mean } \pm \mathrm{SE})^{2}$

\begin{tabular}{lccc}
\hline & \multicolumn{2}{c}{ Treatment $^{4}$} \\
Sorting of particle \\
\cline { 2 - 3 } fractions $^{3}(\%)$ & Long & Short & \multirow{2}{*}{$P$-value } \\
\hline Long & $94.2 \pm 1.9^{*}$ & $99.7 \pm 1.9$ & 0.049 \\
Medium & $100.0 \pm 0.8$ & $101.8 \pm 0.8^{*}$ & 0.12 \\
Short & $100.7 \pm 0.5$ & $101.3 \pm 0.5^{*}$ & 0.44 \\
Fine & $99.8 \pm 1.2$ & $96.8 \pm 1.2^{*}$ & 0.08 \\
\hline
\end{tabular}

${ }^{1}$ Sorting $=$ DMI refused $/$ DMI predicted for each fraction. Sorting $\%=$ 100 means no sorting occurred, $<100$ means sorting occurred against, and $>100$ means sorting occurred in favor.

${ }^{2}$ Long, $\mathrm{n}=20$ cows; short, $\mathrm{n}=21$ cows.

${ }^{3}$ Particle size determined by Penn State particle separator (Nasco, Fort Atkinson, WI), which has a 19-mm screen (long), 8-mm screen (medium), 4-mm screen (short), and a pan (fine).

${ }^{4}$ Long: TMR with long (chopped with 5.08 -cm screen) wheat straw particles; Short: TMR with short (chopped with 2.54-cm screen) wheat straw particles.

*Difference in sorting values from $100 \%(P<0.05)$. All other values are $P>0.05$. 
Table 4. Effect of straw particle size on the DMI and feeding behavior of lactating dairy cows ${ }^{1}$ in the first 28 $\mathrm{d}$ of lactation (mean $\pm \mathrm{SE}$ )

\begin{tabular}{|c|c|c|c|}
\hline \multirow[b]{2}{*}{ Item } & \multicolumn{2}{|c|}{ Treatment $^{2}$} & \multirow[b]{2}{*}{$P$-value } \\
\hline & Long & Short & \\
\hline$\overline{\mathrm{DMI}}(\mathrm{kg} / \mathrm{d})$ & $19.0 \pm 0.5$ & $19.0 \pm 0.5$ & 0.98 \\
\hline DMI as a percentage of BW (\%) & $2.6 \pm 0.08$ & $2.6 \pm 0.08$ & 0.86 \\
\hline Feeding time $(\min / \mathrm{d})$ & $163.0 \pm 8.7$ & $163.3 \pm 8.5$ & 0.98 \\
\hline Feeding rate ( $\mathrm{kg}$ of $\mathrm{DM} / \mathrm{min})$ & $0.14 \pm 0.006$ & $0.14 \pm 0.006$ & 0.90 \\
\hline Meal frequency (meals/d) & $9.5 \pm 0.5$ & $9.2 \pm 0.5$ & 0.66 \\
\hline Within meal intervals (min) & $4.5 \pm 0.6$ & $4.1 \pm 0.6$ & 0.65 \\
\hline Meal length (min/meal) & $23.4 \pm 1.6$ & $23.1 \pm 1.5$ & 0.89 \\
\hline Meal size (DMI/meal) & $2.2 \pm 0.1$ & $2.3 \pm 0.1$ & 0.50 \\
\hline Intervals between meals (min) & $142.8 \pm 8.4$ & $148.1 \pm 8.0$ & 0.65 \\
\hline Meal criterion $(\min )$ & $18.2 \pm 2.8$ & $18.0 \pm 2.7$ & 0.97 \\
\hline Rumination time $(\mathrm{min} / \mathrm{d})$ & $474.1 \pm 17.7$ & $478.1 \pm 17.3$ & 0.87 \\
\hline
\end{tabular}

${ }^{1}$ Long: $\mathrm{n}=20$ cows; short: $\mathrm{n}=21$ cows.

${ }^{2}$ Long: TMR with long (straw chopped using a $5.08-\mathrm{cm}$ screen) wheat straw particles; short: TMR with short (straw chopped using a $2.54-\mathrm{cm}$ screen) wheat straw particles.

during the study period. No differences were detected between treatments for mean BHB concentration (long: $1.6 \pm 0.15 \mathrm{mmol} / \mathrm{L}$; short: $1.5 \pm 0.15 \mathrm{mmol} / \mathrm{L} ; P=$ 0.66 ), days to first diagnosis of SCK (long: $8.3 \pm 1.2$ d; short: $8.1 \pm 1.2 \mathrm{~d} ; P=0.87)$, and number of SCK diagnoses (long: $4.9 \pm 0.6$; short: $4.3 \pm 0.5 ; P=0.46$ ). We also detected no differences between treatments for cows classified as either a normal or high dry period BCS $(P=0.30)$.

Changes in DMI, reticulorumen $\mathrm{pH}$, time spent below a reticulorumen $\mathrm{pH}$ of 5.8, rumination time, and milk production over the 28-d study period were modeled. The fitted data indicated treatment differences between linear coefficients $(P<0.001)$ for daily DMI (Figure 1$)$. The fitted data for mean daily reticulorumen $\mathrm{pH}$ indicated treatment differences between linear coefficients $(P<0.001 ;$ Figure 2). Treatment differences were noted between the linear coefficients $(P<0.001)$, quadratic coefficients $(P<0.001)$, and cubic coefficients
$(P<0.001)$ for fitted data for mean daily time spent below a reticulorumen $\mathrm{pH}$ of 5.8 (Figure 3 ). We found treatment differences detected between $y$-intercepts $(P$ $=0.05)$, quadratic coefficients $(P<0.001)$, and cubic coefficients $(P<0.001)$ for daily rumination time (Figure 4$)$. The fitted data indicated treatment differences between the linear coefficients $(P<0.001)$, quadratic coefficients $(P<0.001)$, and cubic coefficients $(P<$ 0.001) for daily milk yield (Figure 5 ).

\section{DISCUSSION}

Particle size of the wheat straw included at $9 \%$ of DM to a fresh cow diet had an effect on the feed sorting behavior of early-lactation cows in this study. The short diet did not prevent feed sorting as hypothesized. Instead, cows on the short diet sorted their feed to a small degree in favor of the medium and short particles and sorted against the fine particles. Sorting in favor

Table 5. Effect of straw particle size on the reticulorumen $\mathrm{pH}$ of lactating dairy cows in the first $28 \mathrm{~d}$ of lactation $(\text { mean } \pm \mathrm{SE})^{1}$

\begin{tabular}{|c|c|c|c|}
\hline \multirow[b]{2}{*}{ Item } & \multicolumn{2}{|c|}{ Treatment $^{2}$} & \multirow[b]{2}{*}{$P$-value } \\
\hline & Long & Short & \\
\hline Mean reticulorumen $\mathrm{pH}$ & $6.2 \pm 0.05$ & $6.2 \pm 0.05$ & 0.63 \\
\hline Maximum reticulorumen $\mathrm{pH}$ & $6.6 \pm 0.05$ & $6.6 \pm 0.05$ & 0.50 \\
\hline Minimum reticulorumen $\mathrm{pH}$ & $5.9 \pm 0.05$ & $5.9 \pm 0.05$ & 0.60 \\
\hline Mean time below reticulorumen pH $5.8(\mathrm{~min} / \mathrm{d})$ & $140.9 \pm 47.8$ & $97.6 \pm 48.1$ & 0.53 \\
\hline $\mathrm{AUC}^{3} \mathrm{pH}<5.8(\mathrm{pH} \times \min / \mathrm{d})$ & $19.9 \pm 9.0$ & $15.2 \pm 9.1$ & 0.72 \\
\hline $\mathrm{AUC} / \mathrm{DMI}^{4}$ & $1.0 \pm 0.5$ & $1.1 \pm 0.5$ & 0.96 \\
\hline
\end{tabular}


Table 6. Effect of straw particle size on the milk production and composition of lactating dairy cows in the first $28 \mathrm{~d}$ of lactation $(\text { mean } \pm \mathrm{SE})^{1,2}$

\begin{tabular}{|c|c|c|c|}
\hline \multirow[b]{2}{*}{ Item } & \multicolumn{2}{|c|}{ Treatment $^{3}$} & \multirow[b]{2}{*}{$P$-value } \\
\hline & Long & Short & \\
\hline \multicolumn{4}{|c|}{ Milk production $(\mathrm{kg} / \mathrm{d})$} \\
\hline Milk & $36.4 \pm 1.1$ & $38.1 \pm 1.1$ & 0.31 \\
\hline $4 \% \mathrm{FCM}$ & $44.4 \pm 1.7$ & $46.2 \pm 1.6$ & 0.45 \\
\hline ECM & $48.5 \pm 2.9$ & $52.2 \pm 3.0$ & 0.38 \\
\hline \multicolumn{4}{|c|}{ Milk composition $(\%)$} \\
\hline Fat & $5.1 \pm 0.1$ & $5.2 \pm 0.1$ & 0.79 \\
\hline Protein & $4.1 \pm 1.0$ & $4.3 \pm 0.94$ & 0.90 \\
\hline \multicolumn{4}{|c|}{ Milk component yield $(\mathrm{kg} / \mathrm{d})$} \\
\hline Fat & $1.9 \pm 0.08$ & $2.0 \pm 0.1$ & 0.56 \\
\hline Protein & $1.5 \pm 0.4$ & $1.8 \pm 0.4$ & 0.62 \\
\hline \multicolumn{4}{|c|}{ Efficiency of milk production $(\mathrm{kg} / \mathrm{kg})$} \\
\hline Milk/DMI & $2.0 \pm 0.06$ & $2.1 \pm 0.06$ & 0.49 \\
\hline $4 \% \mathrm{FCM} / \mathrm{DMI}$ & $2.3 \pm 0.09$ & $2.5 \pm 0.08$ & 0.27 \\
\hline ECM/DMI & $2.5 \pm 0.2$ & $2.8 \pm 0.2$ & 0.27 \\
\hline MUN (mg/dL) & $10.4 \pm 0.5$ & $10.0 \pm 0.4$ & 0.62 \\
\hline $\log \mathrm{SCC}^{4}$ & $4.7 \pm 0.2$ & $4.7 \pm 0.3$ & 0.98 \\
\hline
\end{tabular}

${ }^{1}$ Long, $\mathrm{n}=20$ cows; short, $\mathrm{n}=21$ cows.

${ }^{2}$ Milk composition and efficiency data were averaged over $2 \mathrm{~d} / \mathrm{wk}$.

${ }^{3}$ Long: TMR with long (straw chopped using a 5.08-cm screen) wheat straw particles; short: TMR with short (straw chopped using a 2.54-cm screen) wheat straw particles.

${ }^{4}$ Somatic cell counts (cells $/ \mathrm{mL}$ ) were log-transformed, given that they did not meet the assumption of normality.

of some of the longer dietary particles and against the finest particles is unusual because cows typically sort in the opposite direction, favoring the shorter particles and avoiding the longer particles (Miller-Cushon and DeVries, 2017). Comparatively, cows fed the diet with longer straw particles sorted against the longest ration

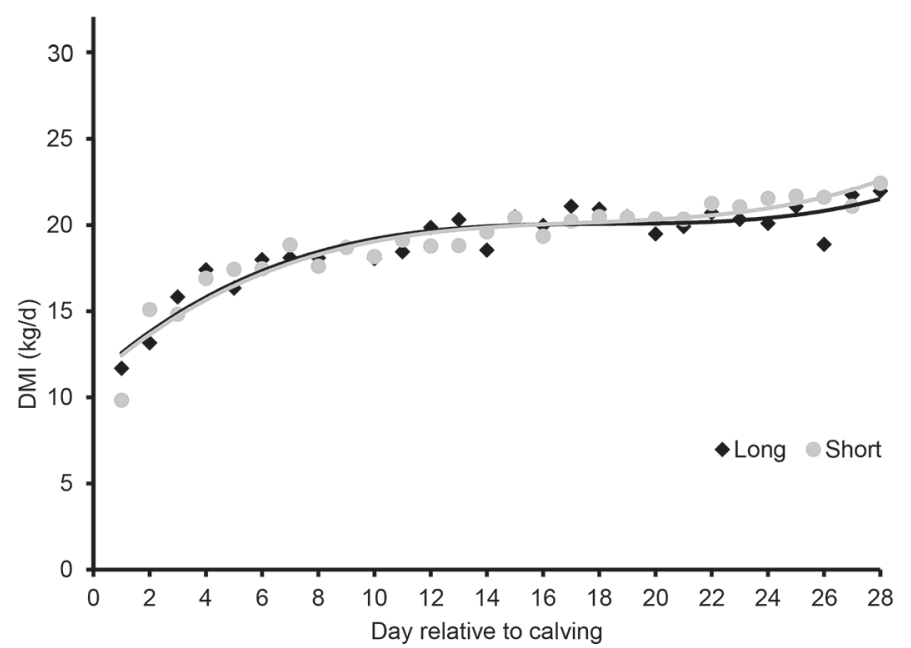

Figure 1. Daily DMI (kg/d) for cows fed 1 of 2 dietary treatments differing in the length of the wheat straw component: (1) straw chopped using a 2.54-cm screen (short: $\mathrm{n}=21$ cows) or (2) straw chopped using a 5.08 -cm screen (long: $\mathrm{n}=20$ cows). Trend lines were constructed using analysis of covariance: $\mathrm{y}=1.42 \mathrm{~d}-0.080 \mathrm{~d}^{2}$ $+0.0015 \mathrm{~d}^{3}+11.44$ for the long treatment; $\mathrm{y}=1.46 \mathrm{~d}-0.080 \mathrm{~d}^{2}+$ $0.0015 \mathrm{~d}^{3}+11.15$ for the short treatment. particles. Greater sorting against these long particles on that diet was hypothesized, as researchers have revealed that cows demonstrate more sorting against long particles when particle size is more easily distinguished (Oelker et al., 2009; DeVries and Gill, 2012). We also noted greater NDF content in the longest particle

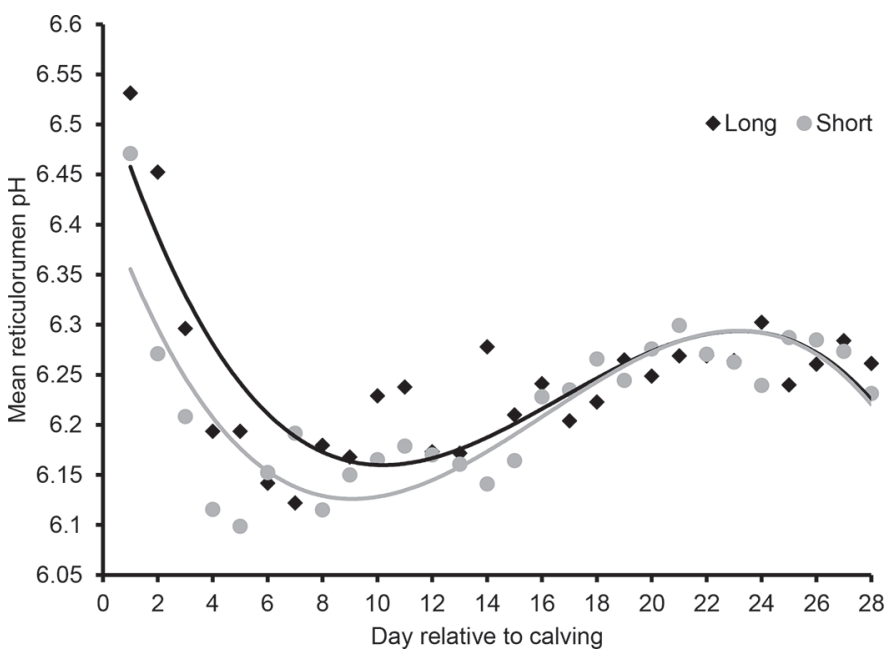

Figure 2. Mean daily reticulorumen $\mathrm{pH}$ for cows fed 1 of 2 dietary treatments differing in the length of the wheat straw component: (1) straw chopped using a 2.54 -cm screen (short, $\mathrm{n}=19$ cows) or (2) straw chopped using a $5.08-\mathrm{cm}$ screen (long, $\mathrm{n}=19$ cows). Trend lines were constructed using analysis of covariance: $\mathrm{y}=-0.083 \mathrm{~d}+0.0060 \mathrm{~d}^{2}-$ $0.00012 \mathrm{~d}^{3}+6.51$ for the long treatment; $\mathrm{y}=-0.080 \mathrm{~d}+0.0060 \mathrm{~d}^{2}-$ $0.00012 \mathrm{~d}^{3}+6.43$ for the short treatment. 


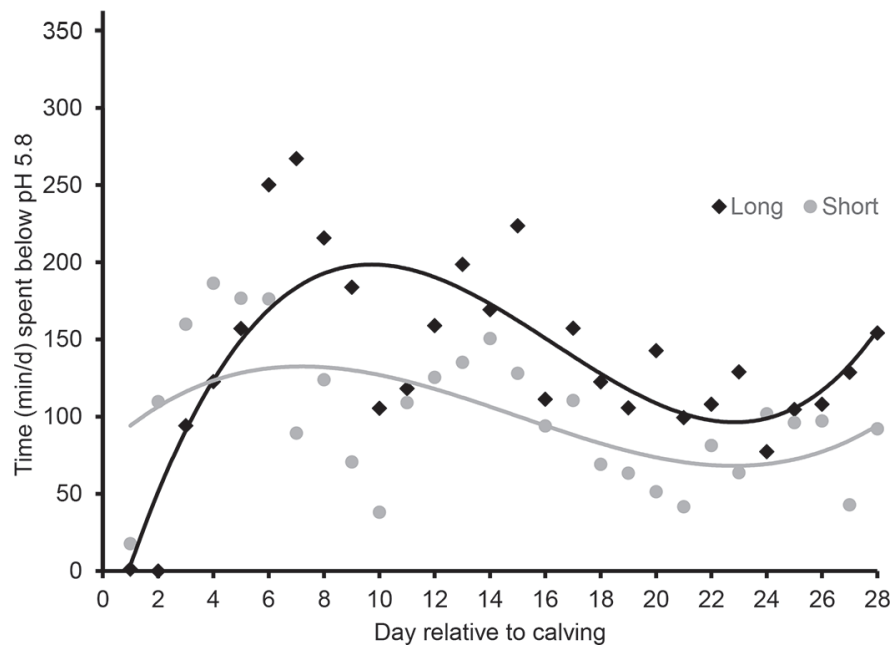

Figure 3. Mean time $(\mathrm{min} / \mathrm{d})$ spent below a reticulorumen $\mathrm{pH}$ of 5.8 for cows fed 1 of 2 dietary treatments differing in the length of the wheat straw component: (1) straw chopped using a 2.54-cm screen (short: $\mathrm{n}=21$ cows) or $(2)$ straw chopped using a $5.08-\mathrm{cm}$ screen (long: $\mathrm{n}=20$ cows). Trend lines were constructed using analysis of covariance: $\mathrm{y}=61.11 \mathrm{~d}-4.53 \mathrm{~d}^{2}+0.091 \mathrm{~d}^{3}-33.73$ for the long treatment; $\mathrm{y}=16.13 \mathrm{~d}-1.50 \mathrm{~d}^{2}+0.032 \mathrm{~d}^{3}+93.88$ for the short treatment.

fraction of the long ration compared with that in the short ration, which was expected given the differences in particle size of the straw in both diets. As cows will sort against NDF (DeVries et al., 2007), this greater proportion of NDF further explains why cows on the long treatment sorted against the longest particle fraction to a greater extent.

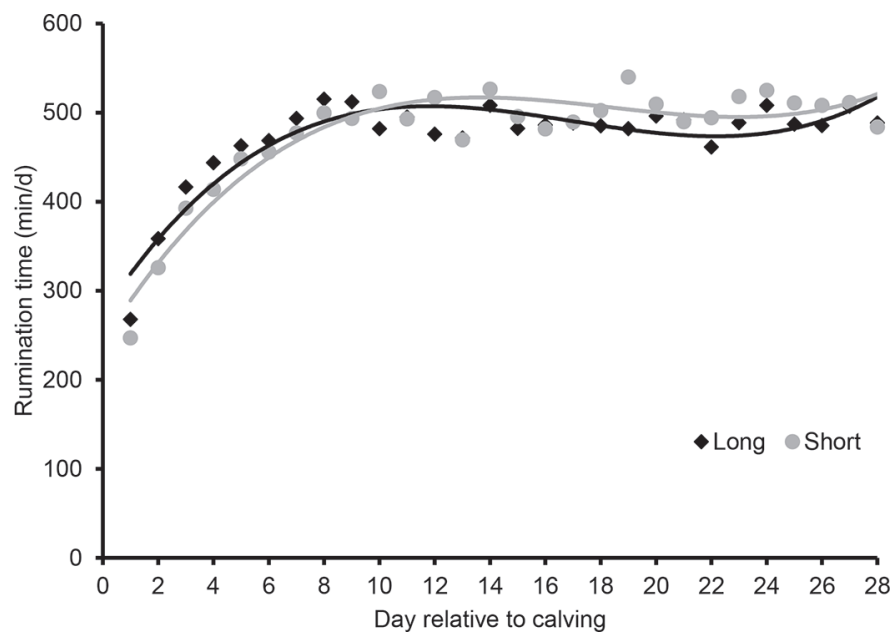

Figure 4. Mean rumination time ( $\mathrm{min} / \mathrm{d})$ postcalving for cows fed 1 of 2 dietary treatments differing in the length of the wheat straw component: (1) straw chopped using a 2.54-cm screen (short, $\mathrm{n}=21$ cows) or (2) straw chopped using a 5.08-cm screen (long, $\mathrm{n}=20$ cows). Trend lines were constructed using analysis of covariance: $\mathrm{y}=47.85 \mathrm{~d}$ $-3.12 \mathrm{~d}^{2}+0.061 \mathrm{~d}^{3}+278.43$ for the long treatment; $\mathrm{y}=47.85 \mathrm{~d}-$ $2.67 \mathrm{~d}^{2}+0.047 \mathrm{~d}^{3}+229.93$ for the short treatment.

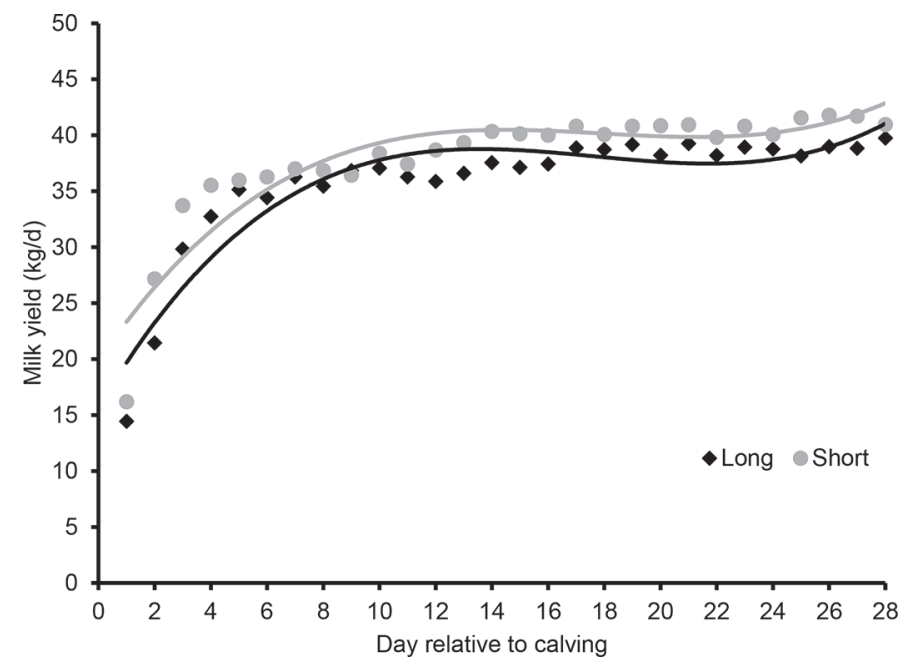

Figure 5. Mean daily milk yield for cows fed 1 of 2 dietary treatments differing in the length of the wheat straw component: (1) straw chopped using a 2.54-cm straw screen (short, $\mathrm{n}=21$ cows) or (2) straw chopped using a 5.08 -cm screen (long, $\mathrm{n}=20$ cows). Trend lines were constructed using analysis of covariance: $\mathrm{y}=4.081 \mathrm{~d}-0.24 \mathrm{~d}^{2}$ $+0.0044 \mathrm{~d}^{3}+17.44$ for the long treatment; $\mathrm{y}=3.13 \mathrm{~d}-0.18 \mathrm{~d}^{2}+$ $0.0032 \mathrm{~d}^{3}+22.34$ for the short treatment.

We found no detectable differences between treatments for mean $\mathrm{pH}$, maximum $\mathrm{pH}$, and minimum $\mathrm{pH}$, summarized on a weekly basis. When day-to-day changes were analyzed over time, cows on the long treatment experienced a greater linear decrease in reticulorumen $\mathrm{pH}$ during the first 7 to 10 DIM than cows on the short treatment. Sorting against the long particles by cows on the long treatment may have contributed to a less stable reticulorumen environment. DeVries et al. (2008) demonstrated that sorting against long particles was associated with depressed rumen $\mathrm{pH}$. Similarly, despite no treatment differences in mean time $(\mathrm{min} / \mathrm{d})$ spent below a reticulorumen $\mathrm{pH}$ of 5.8 , the regression analysis revealed differences in how time spent below a reticulorumen $\mathrm{pH}$ of 5.8 varied by treatment across the first 28 DIM. During the first 10 DIM, cows on the long treatment exhibited a greater linear increase in time spent below a reticulorumen $\mathrm{pH}$ of 5.8 than cows on the short treatment. Between 10 and 23 DIM the opposite effect was observed, with long cows experiencing a greater decrease in time spent below a reticulorumen $\mathrm{pH}$ of 5.8. Cows on the long diet sorted against the longest, and most physically effective components, of the feed; this may have altered the buffering capacity of the reticulorumen (Zebeli et al., 2012) and thus contributed to greater fluctuations in reticulorumen $\mathrm{pH}$. The fluctuation over time in reticulorumen $\mathrm{pH}$ observed in cows on the long treatment was unexpected given that the $\mathrm{pH}$ of fluid in the reticulum, where the bolus was mostly situated, fluctuates to a lesser degree than ruminal fluid 
pH (Falk et al., 2016). Falk et al. (2016) suggested that the reason reticular $\mathrm{pH}$ is more stable is because the reticulum is smaller than the rumen and the contents are less varied; s smaller reticular volume likely minimizes movement of the bolus; this stabilization may provide more consistent measurements. Additionally reticulum contents have a higher $\mathrm{pH}$ than those of the rumen (Sato et al., 2012). Sato et al. (2012) suggested that a reticular $\mathrm{pH}$ of 6.3 or less was indicative of SARA, but did not provide a minimum time requirement for this threshold. It is possible that more pronounced differences between treatments in measures of $\mathrm{pH}$ in the current study may have been observed if measurement of $\mathrm{pH}$ were taken within the ventral rumen sac.

Despite a lack of a detectable difference in weekly mean DMI between treatment groups, when expressed as a change over time, cows on the short diet had a greater linear daily increase in DMI over the duration of the trial than cows on the long diet. A plateau in DMI was observed for both treatment groups between approximately 10 and 20 DIM, which is unusual for fresh cows, who typically experience a rapid increase in DMI in early lactation (Kertz et al., 1991). To ensure that any differences between the 2 treatment diets were discernible, the straw content of the diets was higher than what allowed for maximal DMI in cows averaging $122 \pm 62$ DIM (9 vs 5\% DM; Eastridge et al., 2017). Thus, it is possible that the DMI of cows on both trial diets were limited at around 10 DIM because of the high straw content. It is well established that wheat straw has lower NDF degradability, in comparison to many other forages (Spanghero et al., 2010); thus, its inclusion in a diet may increase the filling effect of said diet. Consequently, in the present study, the straw (at 9\% DM inclusion) may have filled the rumen and limited intake, as was speculated in a recent study using a diet with 10\% (DM) wheat straw (Eastridge et al., 2017). However, McCarthy et al. (2015c) suggested that DMI was limited by rumen fill when NDF intake reached $1.1 \%$ of $\mathrm{BW}$ in the first 3 wk of lactation for cows fed a diet with $11.5 \%$ DM wheat straw (McCarthy et al., 2015a,b). At no time in the present study did mean daily NDF intake, as a percentage of BW, reach $1.1 \%$, suggesting that DMI was not limited only by the filling effect of the amount of straw in the diets.

An alternative explanation for the plateau in DMI is that it is related to the rapid decline in reticulorumen $\mathrm{pH}$ observed in the first 10 DIM. The beginning of the plateau in DMI immediately follows the peak in time spent below a reticulorumen $\mathrm{pH}$ of 5.8 at 7 to 10 DIM, when cows on the long treatment spent 267 $\mathrm{min} / \mathrm{d}$ below this $\mathrm{pH}$ threshold. Whereas no definitive parameters exist for how long reticulorumen $\mathrm{pH}$ must be depressed to diagnose SARA, it is generally ac- cepted that $\mathrm{pH}$ must be below 5.8 for several hours per day (Plaizier et al., 2008). With this threshold in mind, it seems plausible that cows on both treatments were experiencing SARA in the first 10 DIM, the symptoms of which include decreased DMI and milk production (Plaizier et al., 2008). In support of this theory, cows on the short treatment tended to produce $76 \mathrm{~kg}$ more milk over the first 28 DIM than cows on the long treatment, possibly due to consumption of a more consistent diet (relative to that predicted) and greater stability in their reticulorumen environment. These results are supported by Sova et al. (2013), who observed that group-level sorting against long particles was associated with decreased FCM yield, possibly as a result of a less stable reticulorumen environment.

Aside from time spent not eating within a meal, feeding behavior was unaffected by treatment. This was not expected, as changing forage particle size has been shown to affect time spent chewing for oat silage, corn silage, and alfalfa hay (Kononoff and Heinrichs, 2003; Leonardi et al., 2005b; Kahyani et al., 2013). However, Suarez-Mena et al. (2013) did not find a difference in time spent eating, chewing, or ruminating for nonlactating cows fed a diet differing in straw particle size, which is consistent with the findings of the current study. It may be that the difference between treatments in straw particle size, in both studies, was not large enough to elicit a response in chewing time. In the first week of lactation cows on the long treatment tended to spend more time not eating within a meal than cows on the short treatment. It is possible that the transition to a diet with a longer straw particle size initially required more chewing (Nasrollahi et al., 2016), which resulted in more time spent not actively consuming feed from the bin and greater within-meal intervals. After a period of adaptation, cows on the long treatment may have then been able to reduce the time spent not eating within a meal. However, these results are not supported by Yang and Beauchemin (2006a), who found that increasing the forage particle size of barley silage did not result in more chewing within a meal. The discrepancy between their study and the current study may be the result of differences in forage sources. It is possible that straw takes longer within a meal to chew than silage; support for this is provided by Sudweeks et al. (1981), who demonstrated that oat straw has a higher chewing time per kilogram of DM than other forage sources, such as hay and various silages.

Whereas we detected no treatment differences in weekly mean time spent ruminating, straw particle size did affect how time spent ruminating evolved over the first 28 DIM. Cows on the short treatment showed less fluctuation in rumination time after 10 DIM. Cows on the short treatment had a lower initial daily rumination 
time after calving than cows on the long treatment but recovered faster in the first 10 DIM. These results are consistent with the stabilization of reticulorumen $\mathrm{pH}$ in cows on the short treatment, likely due to the difference in sorting behavior on that diet, as discussed above. Stimulating rumination by feeding forage is important for maintaining a stable reticulorumen environment because rumination results in increased rates of salivation, which then buffers the reticulorumen $\mathrm{pH}$ (Oba and Allen, 1999).

Milk yield evolved differently by treatment across the first 28 DIM. During the first 10 DIM, cows on long treatment exhibited a greater linear increase in milk yield. However, after this initial surge in milk yield, cows on both treatments experienced a plateau in daily milk yield, which slightly declined until 23 DIM. A high incidence rate of SCK across treatments, in addition to the plateau in DMI, may explain why a plateau in milk yield occurred for both treatment groups. Of the 41 cows used in this trial, 38 (long, $\mathrm{n}=18$; short, $\mathrm{n}=20$ ) were diagnosed with SCK at least once during the trial period. There is an association between decreased milk production and increased BHB concentrations postcalving (Ospina et al., 2010); thus, this higher than expected incidence rate of SCK may have contributed to the plateau in milk yield observed in our study (Ospina et al., 2010; McArt et al., 2012). It is also interesting to note that, based on the fitted data, cows on the long treatment experienced greater declines in milk yield compared with cows on the short treatment from 10 to 23 DIM. This difference is likely not the result of $\mathrm{SCK}$, as we found no treatment differences in measures of BHB concentration. It is more plausible that greater fluctuations in reticulorumen $\mathrm{pH}$ and rumination during the same time period, created by sorting against the longest particles in the ration, resulted in more variable milk yield for cows on the long treatment over the first 28 DIM.

\section{CONCLUSIONS}

Over the first 28 DIM, cows sorted in favor of the medium and short particles and against the finest ration particles when fed a diet containing shorter chopped wheat straw. In contrast, cows sorted against the longest ration particles during that time period when the diet contained longer chopped wheat straw. These differences in sorting behavior explain why cows fed the diet with the shorter chopped straw demonstrated more stability in their rumination and reticulorumen $\mathrm{pH}$ over the first $28 \mathrm{~d}$ of lactation. Consequently, cows fed a diet with a shorter straw particle size exhibited more stability in their milk production and tended to produce more cumulative milk over that time period than cows fed a diet with straw chopped to a longer particle size. These results highlight the importance of managing forage particle size in early-lactation diets to promote consistency in intake, relative to that predicted, and resultant stability in reticulorumen health and milk yield.

\section{ACKNOWLEDGMENTS}

The authors thank the staff of the University of Guelph, Elora Dairy Research Facility (Elora, ON, Canada). A special thanks to Robin Crossley, Emily Kaufmann, Michelle Thompson, and Kaitlyn Sparkman of the University of Guelph (Guelph, ON, Canada) for helping with data collection and to Laura Wright of the University of Guelph, Elora Dairy Research Facility, for her technical assistance. R. Coon was supported by a Canadian Dairy Commission MSc Scholarship. Financial support was received from the Natural Sciences and Engineering Research Council of Canada (NSERC; Ottawa, ON, Canada) Discovery Grant (T. J. DeVries) and the Ontario Ministry of Agriculture, Food and Rural Affairs (OMAFRA, Guelph, ON, Canada) - University of Guelph Partnership. We thank EastGen (Guelph, ON, Canada), particularly Mark Carson, for contributions towards the rumination monitoring equipment and technical support. Further, project equipment was supported by contributions from the Canadian Foundation for Innovation (CFI; Ottawa, ON, Canada) and the Ontario Research Fund (Toronto, ON, Canada).

\section{REFERENCES}

AOAC International. 2000. Official Methods of Analysis. Vol. I. 17th ed. AOAC International, Arlington, VA.

Canadian Council on Animal Care. 2009. Guidelines on: The Care and Use of Farm Animals in Research, Teaching and Testing. Canadian Council on Animal Care, Ottawa, ON, Canada.

Chapinal, N., D. M. Veira, D. M. Weary, and M. A. G. von Keyserlingk. 2007. Technical note: Validation of a system for monitoring individual feeding and drinking behavior and intake in group-housed cattle. J. Dairy Sci. 90:5732-5736. https://doi.org/ 10.3168/jds.2007-0331.

DeVries, T. J., K. A. Beauchemin, and M. A. G. von Keyserlingk. 2007. Dietary forage concentration affects the feed sorting behavior of lactating dairy cows. J. Dairy Sci. 90:5572-5579. https://doi .org/10.3168/jds.2007-0370.

DeVries, T. J., F. Dohme, and K. A. Beauchemin. 2008. Repeated ruminal acidosis challenges in lactating dairy cows at high and low risk for developing acidosis: feed sorting. J. Dairy Sci. 91:3958 3967. https://doi.org/10.3168/jds.2008-1347.

DeVries, T. J., and R. M. Gill. 2012. Adding liquid feed to a total mixed ration reduces feed sorting behavior and improves productivity of lactating dairy cows. J. Dairy Sci. 95:2648-2655. https:// doi.org/10.3168/jds.2011-4965.

DeVries, T. J., T. Schwaiger, K. A. Beauchemin, and G. B. Penner. 2014. The duration of time that beef cattle are fed a high-grain diet affects feed sorting behavior, both prior to and after acute ruminal acidosis. J. Anim. Sci. 92:1728-1737.

DeVries, T. J., M. A. G. von Keyserlingk, D. M. Weary, and K. A. Beauchemin. 2003. Measuring the feeding behavior of lactating 
dairy cows in early to peak lactation. J. Dairy Sci. 86:3354-3361. https://doi.org/10.3168/jds.S0022-0302(03)73938-1.

Eastridge, M. L., R. A. Starkey, P. N. Gott, E. R. Oelker, A. R. Sewell, B. Mathew, and J. L. Firkins. 2017. Dairy cows fed equivalent concentrations of forage neutral detergent fiber from corn silage, alfalfa hay, wheat straw, and corn stover had similar milk yield and total tract digestibility. Anim. Feed Sci. Technol. 225:81-86. https://doi.org/10.1016/j.anifeedsci.2017.01.013.

Falk, M., A. Münger, and F. Dohme-Meier. 2016. Technical note: A comparison of reticular and ruminal $\mathrm{pH}$ monitored continuously with 2 measurement systems at different weeks of early lactation. J. Dairy Sci. 99:1951-1955. https://doi.org/10.3168/jds.2015-9725.

Geishauser, T., K. Leslie, D. Kelton, and T. Duffield. 1998. Evaluation of five cowside tests for use with milk to detect subclinical ketosis in dairy cows. J. Dairy Sci. 81:438-443. https://doi.org/10.3168/ jds.S0022-0302(98)75595-X

Gillund, P., O. Reksen, Y. T. Grö, and K. Karlberg. 2001. Body condition related to ketosis and reproductive performance in Norwegian dairy cows. J. Dairy Sci. 84:1390-1396. https://doi.org/10.3168/ jds.S0022-0302(01)70170-1.

Hall, M. B. 2009. Analysis of starch, including maltooligosacchardies, in animal feeds: A comparison of methods and a recommended method for AOAC collaborative study. J. AOAC Int. 92:42-49.

Jones, C. M., and J. Heinrichs. 2013. Penn State Particle Separator. Accessed Apr. 4, 2018. https://extension.psu.edu/penn-state -particle-separator.

Kahyani, A., G. R. Ghorbani, M. Khorvash, S. M. Nasrollahi, and K. A. Beauchemin. 2013. Effects of alfalfa hay particle size in high-concentrate diets supplemented with unsaturated fat: chewing behavior, total-tract digestibility, and milk production of dairy cows. J. Dairy Sci. 96:7110-7119. https://doi.org/10.3168/jds.2012 $-6462$

Kanz, P., M. Drillich, D. Klein-Jöbstl, B. Mair, S. Borchardt, L. Meyer, I. Schwendenwein, and M. Iwersen. 2015. Suitability of capillary blood obtained by a minimally invasive lancet technique to detect subclinical ketosis in dairy cows by using 3 different electronic hand-held devices. J. Dairy Sci. 98:6108-6118. https://doi .org/10.3168/jds.2014-8957.

Kertz, A. F., L. F. Reutzel, and G. M. Thomson. 1991. Dry matter intake from parturition to midlactation. J. Dairy Sci. 74:2290-2295. https://doi.org/10.3168/jds.S0022-0302(91)78401-4.

Kononoff, P. J., and A. J. Heinrichs. 2003. The effect of corn silage particle size and cottonseed hulls on cows in early lactation. J. Dairy Sci. 86:2438-2451. https://doi.org/10.3168/jds.S0022 -0302(03)73838-7.

Leonardi, C., and L. E. Armentano. 2003. Effect of quantity, quality, and length of alfalfa hay on selective consumption by dairy cows. J. Dairy Sci. 86:557-564. https://doi.org/10.3168/jds.S0022 -0302(03)73634-0.

Leonardi, C., F. Giannico, and L. E. Armentano. 2005a. Effect of water addition on selective consumption (sorting) of dry diets by dairy cattle. J. Dairy Sci. 88:1043-1049. https://doi.org/10.3168/ jds.S0022-0302(05)72772-7.

Leonardi, C., K. J. Shinners, and L. E. Armentano. 2005b. Effect of different dietary geometric mean particle length and particle size distribution of oat silage on feeding behavior and productive performance of dairy cattle. J. Dairy Sci. 88:698-710. https://doi.org/ 10.3168/jds.S0022-0302(05)72734-X.

MacDonald, P. D. M., and P. E. J. Green. 1988. User's Guide to Program MIX: An interactive program for fitting mixtures of distributions. Release 2.3, January 1988. Ichthus Data Systems, Hamilton, Ontario, Canada.

Maulfair, D. D., M. Fustini, and A. J. Heinrichs. 2011. Effect of varying total mixed ration particle size on rumen digesta and fecal particle size and digestibility in lactating dairy cows. J. Dairy Sci. 94:3527-3536. https://doi.org/10.3168/jds.2010-3718.

McArt, J. A. A., D. V. Nydam, and G. R. Oetzel. 2012. Epidemiology of subclinical ketosis in early lactation dairy cattle. J. Dairy Sci. 95:5056-5066. https://doi.org/10.3168/jds.2012-5443.
McCarthy, M. M., H. Dann, and T. R. Overton. 2015c. Feeding the fresh cow. Pages 171-183 in Proc. Cornell Nutr. Conf. Feed Manuf. Cornell University, Ithaca, NY.

McCarthy, M. M., T. Yasui, C. M. Ryan, S. H. Pelton, G. D. Mechor, and T. R. Overton. 2015a. Performance of early-lactation dairy cows as affected by dietary starch and monensin supplementation. J. Dairy Sci. 98:3335-3350. https://doi.org/10.3168/jds.2014 -8820 .

McCarthy, M. M., T. Yasui, C. M. Ryan, S. H. Pelton, G. D. Mechor, and T. R. Overton. 2015b. Metabolism of early-lactation dairy cows as affected by dietary starch and monensin supplementation. J. Dairy Sci. 98:3351-3365. https://doi.org/10.3168/jds.2014 $-8821$.

Miller-Cushon, E. K., and T. J. DeVries. 2017. Feed sorting in dairy cattle: Causes, consequences, and management. J. Dairy Sci 100:4172-4183. https://doi.org/10.3168/jds.2016-11983.

Morris, T. R. 1999. Experimental Design and Analysis in Animal Sciences. CABI Publishing, New York, NY.

Nasrollahi, S. M., M. Imani, and Q. Zebeli. 2016. A meta-analysis and meta-regression of the impact of particle size, level, source and preservation method of forages on chewing behavior and ruminal fermentation in dairy cows. Anim. Feed Sci. Technol. 219:144-158. https://doi.org/10.1016/j.anifeedsci.2016.06.012.

NRC. 2001. Nutrient Requirements of Dairy Cattle. 7 th rev. ed. Natl. Acad. Press, Washington, DC.

Nombekela, S. W., M. R. Murphy, H. W. Gonyou, and J. I. Marden. 1994. Dietary preferences in early lactation cows as affected by primary tastes and some common feed flavors. J. Dairy Sci. 77:23932399. https://doi.org/10.3168/jds.S0022-0302(94)77182-4.

Oba, M., and M. S. Allen. 1999. Evaluation of the importance of the digestibility of neutral detergent fiber from forage: Effects on dry matter intake and milk yield of dairy cows. J. Dairy Sci. 82:589596. https://doi.org/10.3168/jds.S0022-0302(99)75271-9.

Oelker, E. R., C. Reveneau, and J. L. Firkins. 2009. Interaction of molasses and monensin in alfalfa hay- or corn silage-based diets on rumen fermentation, total tract digestibility, and milk production by Holstein cows. J. Dairy Sci. 92:270-285. https://doi.org/ $10.3168 / j d s .2008-1432$

Ospina, P. A., D. V. Nydam, T. Stokol, and T. R. Overton. 2010. Associations of elevated nonesterified fatty acids and $\beta$-hydroxybutyrate concentrations with early lactation reproductive performance and milk production in transition dairy cattle in the northeastern United States. J. Dairy Sci. 93:1596-1603. https://doi.org/10.3168/jds .2009-2852.

Penner, G. B., M. Taniguchi, L. L. Guan, K. A. Beauchemin, and M. Oba. 2009. Effect of dietary forage to concentrate ratio on volatile fatty acid absorption and the expression of genes related to volatile fatty acid absorption and metabolism in ruminal tissue. J. Dairy Sci. 92:2767-2781. https://doi.org/10.3168/jds.2008-1716.

Plaizier, J. C., D. O. Krause, G. N. Gozho, and B. W. McBride. 2008. Subacute ruminal acidosis in dairy cows: the physiological causes, incidence and consequences. Vet. J. 176:21-31. https://doi.org/10 $.1016 /$ j.tvjl.2007.12.016

Sato, S., A. Ikeda, Y. Tsuchiva, K. Ikuta, I. Murayama, M. Kanehira, K. Okada, and H. Mizuguchi. 2012. Diagnosis of subacute ruminal acidosis (SARA) by continuous reticular $\mathrm{pH}$ measurements in cows. Vet. Res. Commun. 36:201-205. https://doi.org/10.1007/ s11259-012-9528-8.

Schirmann, K., M. A. G. von Keyserlingk, D. M. Weary, D. M. Veira, and W. Heuwieser. 2009. Technical note: Validation of a system for monitoring rumination in dairy cows. J. Dairy Sci. 92:6052-6055. https://doi.org/10.3168/jds.2009-2361.

Schwaiger, T., K. A. Beauchemin, and G. B. Penner. 2013. The duration of time that beef cattle are fed a high-grain diet affects the recovery from a bout of ruminal acidosis: Dry matter intake and ruminal fermentation. J. Anim. Sci. 91:5729-5742. https://doi . org $/ 10.2527 /$ jas. $2013-6471$

Sova, A. D., S. J. LeBlanc, B. W. McBride, and T. J. DeVries. 2013. Associations between herd-level feeding management practices, 
feed sorting, and milk production in freestall dairy farms. J. Dairy Sci. 96:4759-4770. https://doi.org/10.3168/jds.2013-6679.

Spanghero, M., P. Berzaghi, R. Fortina, F. Masoero, L. Rapetti, C. Zanfi, S. Tassone, A. Gallo, S. Colombini, and J. C. Ferlito. 2010. Technical note: Precision and accuracy of in vitro digestion of neutral detergent fiber and predicted net energy of lactation content of fibrous feeds. J. Dairy Sci. 93:4855-4859. https://doi.org/ 10.3168/jds.2010-3098.

Steele, M. A., G. B. Penner, F. Chaucheyras-Durand, and L. L. Guan. 2016. Development and physiology of the rumen and the lower gut: Targets for improving gut health. J. Dairy Sci. 99:4955-4966. https://doi.org/10.3168/jds.2015-10351.

Suarez-Mena, F. X., G. I. Zanton, and A. J. Heinrichs. 2013. Effect of forage particle length on rumen fermentation, sorting and chewing activity of late-lactation and non-lactating dairy cows. Animal 7:272-278. https://doi.org/10.1017/S1751731112001565.

Sudweeks, E. M., L. O. Ely, D. R. Mertens, and L. R. Sisk. 1981. Assessing minimum amounts and form of roughages in ruminant diets: Roughage value index system. J. Anim. Sci. 53:1406-1411.

Tyrrell, H. F., and J. T. Reid. 1965. Prediction of the energy value of cow's milk. J. Dairy Sci. 48:1215-1223. https://doi.org/10.3168/ jds.S0022-0302(65)88430-2.
Van Soest, P. J., J. B. Robertson, and B. A. Lewis. 1991. Methods for dietary fiber, neutral detergent fiber, and nonstarch polysaccharides in relation to animal nutrition. J. Dairy Sci. 74:3583-3597. https://doi.org/10.3168/jds.S0022-0302(91)78551-2.

Wildman, E. E., G. M. Jones, P. E. Wagner, R. L. Boman, H. F. Troutt, and T. N. Lesch. 1982. A dairy cow body condition scoring system and its relationship to selected production characteristics. J. Dairy Sci. 65:495-501. https://doi.org/10.3168/jds.S0022 -0302(82)82223-6.

Yang, W. Z., and K. A. Beauchemin. 2006a. Effects of physically effective fiber on chewing activity and ruminal $\mathrm{pH}$ of dairy cows fed diets based on barley silage. J. Dairy Sci. 89:217-228. https://doi .org/10.3168/jds.S0022-0302(06)72086-0.

Yang, W. Z., and K. A. Beauchemin. 2006b. Increasing the physically effective fiber content of dairy cow diets may lower efficiency of feed use. J. Dairy Sci. 89:2694-2704.

Zebeli, Q., J. R. Aschenbach, M. Tafaj, J. Boguhn, B. N. Ametaj, and W. Drochner. 2012. Invited review: Role of physically effective fiber and estimation of dietary fiber adequacy in high-producing dairy cattle. J. Dairy Sci. 95:1041-1056. https://doi.org/10.3168/ jds.2011-4421. 